ETNIK : Jurnal Ekonomi - Teknik

ISSN: 2808-6694 (Online);2808-7291 (Print)

Jurnal Homepage https://etnik.rifainstitute.com

\title{
Analisis Pembangunan Ekonomi Melalui Pengembangan Potensi UMKM di Era Pandemi Covid 19 di Kota Medan
}

\author{
Nuh Aulya Sari Lubis, Nurul Rafiqoh Lubis, Rifta Alvira, Shofiya Hanifah, \\ Sari Wulandari
}

Universitas Islam Negeri Sumatera Utara

\begin{abstract}
Informasi Artikel
Histori Artikel:

Diterima 11 January 2022

Direvisi 16 January 2022

Diterbitkan 20 January 2022

Email Author:

nuhaulya000@gmail.com

riftaalvira13@gmail.com

shofiyahanifah23@gmail.com

sariwulandarie29@gmail.com
\end{abstract}

\begin{abstract}
Since the arrival of the Covid-19 phenomenon, it has changed people's consumption behavior a lot, at the beginning of the Covid19 Pandemi it proved that the Covid-19 disaster greatly affected the health, social, tourism, and economic conditions of an area. Regions that basically rely on the most superior economic sector for regional progress, have finally been neglected due to the arrival of this virus. One of them is MSMEs, currently MSMEs are experiencing various problems such as declining sales, capital, hampered distribution, difficulty in raw materials, declining production and layoffs of workers, this is a threat to the national economy. This research focuses on the generation and development of MSMEs by utilizing digital technology into businesses and the government's efforts to facilitate MSMEs to grow the Indonesian economy during the Covid-19 Pandemi, which has existed since the beginning of 2019 and has had many negative impacts on the world's economic sector, including Indonesia. The data collection technique in this research is library research. The type of data used is secondary data in the form of books, journals, articles, brochures, and other data relevant to the research theme. The results of this study are how business actors use digital technology in making new product innovations and how the government revives the economic sector by facilitating MSMEs.
\end{abstract}

Keyword-Economic Development, MSMEs, Covid-19

\section{ABSTRAK}

Sejak datangnya fenomena Covid-19 telah banyak mengubah perilaku konsumsi masyarakat, di awal pandemi Covid-19 membuktikan bahwa bencana Covid-19 sangat berpengaruh terhadap kondisi kesehatan, sosial, pariwisata, dan ekonomi suatu daerah. Daerah yang pada dasarnya mengandalkan sektor ekonomi yang paling unggul untuk kemajuan daerahnya, akhirnya terbengkalai karena datangnya virus ini. Salah satunya UMKM, pada saat ini UMKM mengalami berbagai permasalahan 
seperti penurunan penjualan, permodalan, distribusi terhambat, kesulitan bahan baku, produksi menurun dan PHK buruh, hal ini menjadi ancaman bagi perekonomian nasional. Penelitian ini berfokus kepada pembangkitan dan perkembangan UMKM dengan memanfaatkan teknologi digital kedalam usaha serta upaya pemerintah dalam memfasilitasi UMKM untuk menumbuhkan ekonomi Indonesia dimasa pandemi Covid-19 yang sudah ada sejak awal tahun 2019 dan membawa banyak dampak buruk kepada sektor perekonomian dunia termasuk Indonesia. Teknik pengumpulan data dalam penelitian ini adalah library research. Jenis data yang yang digunakan adalah data sekunder berupa buku, jurnal, artikel, brosur, dan data lainnya yang relevan dengan tema penelitian. Hasil dari penelitian ini adalah bagaimana pelaku usaha memanfaatkan teknologi digital dalam membuat inovasi produk baru dan cara pemerintah membangkitkan kembali sektor perekonomian dengan memfasilitasi UMKM.

Kata Kunci - Pembangunan Ekonomi, UMKM, Covid-19

\section{PENDAHULUAN}

Sejak datangnya fenomena Covid-19 telah banyak mengubah perilaku konsumsi masyarakat. Di awal pandemi Covid-19 membuktikan bahwa bencana Covid-19 sangat berpengaruh terhadap kondisi kesehatan, sosial, pariwisata, dan ekonomi suatu daerah (Sumarni, 2020). Daerah yang pada dasarnya mengandalkan sektor ekonomi yang paling unggul untuk kemajuan daerahnya, akhirnya terbengkalai karena datangnya virus ini. Salah satunya UMKM, pada saat ini UMKM mengalami berbagai permasalahan seperti penurunan penjualan, permodalan, distribusi terhambat, kesulitan bahan baku, produksi menurun dan PHK buruh, hal ini menjadi ancaman bagi perekonomian nasional (Aminah, 2020). UMKM sebagai penggerak ekonomi domestik dan penyerap tenaga kerja tengah menghadapi penurunan produktivitas yang berakibat pada penurunan profit secara signifikan. Untuk dapat berkembang, UMKM harus mampu mengoptimalkan potensi untuk meningkatkan daya saingnya, karena dalam menjalankan usahanya, UMKM akan selalu menghadapi persaingan. Dalam menjalankan bisnisnya, persaingan merupakan kondisi yang tidak dapat dihindari oleh UMKM. Beberapa masalah yang sering dihadapi UMKM adalah ketersediaan modal, pemasaran, kurangnya pengetahuan dan rendahnya kualitas sumber daya manusianya. Pengetahuan yang dimiliki sumber daya manusia merupakan faktor penting untuk meningkatkan daya saing perusahaan. Faktor ini merupakan kelemahan terbesar dari usaha mikro kecil dan menengah. Menurut (Muttaqin \& Murtadho, 2011), rendahnya penguasaan pengetahuan pada UMKM dan koperasi dipengaruhi faktor internal dan faktor eksternal. Faktor-faktor tersebut diperparah dengan kondisi Pandemi Covid-19. Dampak pandemi di sektor ekonomi tentunya tidak hanya dirasakan oleh pelaku ekonomi besar, tapi juga sangat terasa bagi pelaku UMKM. Terjadinya penurunan penjualan, bahan baku produk yang sulit diperoleh, dan kesulitan dalam pemasaran merupakan kendala yang dihadapi para pelaku UMKM, khususnya di Kota Medan.

Namun, seiring berjalannya waktu UMKM lah yang memiliki daya pertahanan yang terbaik dalam memajukan perekonomian Indonesia ditengah-tengah pandemi Covid 19. Dengan memanfaatkan E-commerse, UMKM dapat berkembang dengan baik dengan bantuan-bantuan 
digital marketing yang tersedia di e-commerse. Peluang bisnis UMKM itu tak terbatas (unlimited), bidang apa saja bisa berpotensi untuk dijadikan bisnis UMKM meskipun sedang terjadi wabah Covid 19 asalkan para pelaku UMKM memiliki banyak ide kreatif, keahlian dan ketrampilan yang bisa dijual secara online dan offline. Sementara Tantangan pada UMKM yang terjadi saat ini adalah persaingan yang harus dihadapi dengan menghasilkan beragam inovasi dan layanan untuk dapat terus bertahan di pasar lokal, dan juga bisa bersaing di pasar Internasional. Pengembangan bisnis UMKM yang sudah berbasis digital dan begitu mudah di akses telah memacu banyak pergerakan ekonomi diberbagai pelosok daerah. Dewasa ini potensi industri kreatif memiliki prospek peluang yang menjanjikan, Jika banyak industri kreatif di Indonesia terus digali dan ditingkatkan oleh UMKM maka daya serap ekonomi baik di kota maupun di desa akan tersebar merata dan berdaya serap semakin tinggi sehingga pada akhirnya bisa meningkatkan kemakmuran ekonomi di daerah tersebut dan memberikan peluang lapangan kerja agar dapat mengentaskan tingkat kemiskinan. Jumlah UMKM saat ini sudah mencapai lebih dari 56 juta tentunya dengan jumlah yang sangat besar ini UMKM dapat memberikan peran yang baik dalam memajukan perekonomian Indonesia ditengah pandemi Covid 19 (Lili Marlinah, 2020).

Kemudian, dengan uraian UMKM tersebut, dapat ditarik kesimpulan UMKM merupakan penopang kelancaran dan stabilitas perekonomian nasional. Adapun intisarinya adalah bahwa terlepas dari besarnya peran yang diberikan UMKM untuk pembangunan ekonomi, efektifitas pemberdayaan UMKM saat ini perlu dipertanyakan lagi, karena UMKM saat ini masih didominasi dengan usaha mikro. Selain itu, struktur UMKM perlu diubah seperti negara maju agar target yang dihasilkan UMKM menjadi sangat besar.

\section{METODE}

Penelitian ini merupakan penelitian kualitatif, menurut Poerwandari dalam (Rianti, 2016) penelitian kualitatif adalah penelitian yang menghasilkan serta mengolah data dimana sifatnya deskriptif seperti wawancara, catatan lapangan, foto, rekaman, transkripsi dan lain-lain. Tujuan penelitian kualitatif adalah untuk mendapatkan gambaran yang sifatnya umum terhadap kehidupan sosial berdasarkan perpektif partisipan. Jenis data yang digunakan dalam penelitian ini adalah data sekunder, adalah data yang diperoleh atau dikumpulkan oleh orang yang melakukan penelitian dari sumber-sumber yang telah ada (Helmi, 2021). Data sekunder berupa buku-buku, jurnal, majalah, surat kabar, brosur, ensiklopedia, artikel dan data lainnya yang relevan dengan permasalahan pembangunan ekonomi melalui pengembangan potensi UMKM di era pandemi. Dimana data tersebut berupa tulisan ilmiah yang sudah terbukti kevalidannya secara akademik. Teknik pengumpulan data yang digunakan dalam penelitian ini adalah metode library research. Library research atau biasa disebut teknik kepustakaan adalah penelitian kepustakaan yang dilakukan dengan cara membaca, mencatat serta menelaah berbagai literatur atau bahan bacaan yang sesuai dengan pokok bahasan, kemudian disaring dan dituangkan dalam kerangka pemikiran secara teoritis (Kartono, 1976).

\section{HASIL DAN PEMBAHASAN}

\section{Strategi Membangkitkan UMKM Ditengah Pandemi Covid 19 Dengan Penggunaan Teknologi Digital}

Teknologi merupakan suatu metode ilmiah untuk mencapai tujuan praktis yang diperlukan bagi 
kelangsungan dan kenyamanan hidup manusia. Sedangkan secara etimologis, akar kata teknologi adalah "techne" yang berarti serangkaian prinsip atau metode rasional yang berkaitan dengan pembuatan suatu objek, atau kecakapan tertentu, atau pengetahuan tentang prinsip-prinsip atau metode, dan seni (Liu \& Sukmariningsih, 2021). Digital berasal dari kata Digitus, dalam bahasa Yunani berarti jari jemari. Apabila kita hitung jari jemari orang dewasa, maka berjumlah sepuluh. Sehingga menurut penelitian ini, teknologi digital merupakan hasil perkembangan penggunaan peralihan dari cara-cara yang sederhana menjadi cara-cara yang praktis untuk mencapai kelangsungan hidup manusia. Karena pandemi, masyarakat dipaksa oleh keadaan untuk melakukan sesuatu di luar kebiasaan. Untuk menyikapi keadaan tersebut dilakukan terobosan terobosan sehingga pengaturan penggunaan teknologi digital bagi UMKM menjadi fokus pengembangan penelitian ini. Terbukti bahwa teknologi sudah menjadi kebutuhan, dan merata di setiap segi kehidupan manusia. Hal ini setelah adanya penemuan komputer dan laptop, di mana saat ini dalam hampir semua pekerjaan manusia memiliki hubungan dengan komputer ataupun laptop, sehingga pantas jika dikatakan bahwa komputer adalah penemuan yang paling mutakhir dan yang paling berpengaruh pada kehidupan manusia. Perubahan yang paling mendasar di saat pandemi Covid-19 adalah dalam memaknai pembangunan bukan hanya parsial tetapi universal termasuk pembangunan manusia seutuhnya. Pola pikir masyarakat yang mulai harus merubah dirinya menjadi care dengan penguasaan teknologi digital. Meskipun pandemi Covid-19 mengakibatkan beberapa dampak bagi memunculkan pelaku UMKM dan koperasi, tetapi di sisi lain ada peluang yang besar muncul dalam memanfaatkan adanya teknologi informasi untuk mengoptimalkan omzet penjualan atau bahkan menciptakan produk baru dengan memanfaatkan internet. Mengingat data dalam perdagangan elektronik di masa pandemi Covid-19 mencapai US\$130 miliar ini merupakan jumlah yang luar biasa bagi pelaku UMKM (Amri, 2020).

Selanjutnya ekonomi rakyat dan demokrasi ekonomi yang didasarkan pada Pancasila dan UUD Negara Republik Indonesia Tahun 1945 adalah cita-cita dari para pendiri Republik Indonesia ini. Dalam sistem ini perekonomian berorientasi kepada Ketuhanan Yang Maha Esa (adanya etik dan moral agama, bukan materialisme semata), Kemanusiaan yang adil dan beradab (tidak mengenal kekerasan dan eksploitasi manusia), Persatuan Indonesia (kekeluargaan, kebersamaan, nasionalisme dan patriotisme ekonomi), Kerakyatan (mengutamakan ekonomi rakyat dan hajat hidup orang banyak) serta Keadilan sosial (persamaan dan kemakmuran masyarakat yang utama, bukan kemakmuran individu atau kelompok). Di Indonesia sudah terdapat UMKM yang mempersiapkan diri atas penggunaan teknologi digital dengan mulai tampak berjualan di media online. Namun, masih banyak juga yang belum bersentuhan dengan internet, apalagi berjualan via online. Berdasarkan Undang-Undang Nomor 20 Tahun 2008 Tentang UMKM, usaha mikro adalah 
usaha produktif milik orang perorangan dan/atau badan usaha perorangan yang memenuhi kriteria usaha mikro sebagaimana diatur dalam UU tersebut; Usaha kecil adalah usaha ekonomi produktif yang berdiri sendiri, yang dilakukan oleh orang perorangan atau badan usaha yang bukan yang bukan merupakan anak perusahaan atau bukan cabang perusahaan yang dimiliki, dikuasai, atau menjadi bagian baik langsung maupun tidak langsung dari usaha menengah atau usaha besar yang memenuhi kriteria usaha kecil sebagaimana dimaksud dalam UU tersebut; Usaha menengah adalah usaha ekonomi produktif yang berdiri sendiri, yang dilakukan oleh orang perorangan atau badan usaha yang bukan yang bukan merupakan anak perusahaan atau cabang perusahaan yang dimiliki, dikuasai, atau menjadi bagian baik langsung maupun tidak langsung dengan usaha kecil atau usaha besar dengan jumlah kekayaan bersih atau hasil penjualan tahunan sebagaimana diatur dalam UU tersebut.

\section{TABEL 1. KRITERIA UMKM}

\begin{tabular}{|c|l|l|}
\hline KRITERIA USAHA & ASET & OMSET \\
\hline 1. Usaha Mikro & Mksimal 50 juta & Maksimal 300 juta \\
\hline 2. Usaha Kecil & $>50$ juta -500 juta & $>300$ juta $-2,5$ miliar \\
\hline 3. Usaha Menengah & $>500$ juta -10 miliar & $>2,5$ miliar -50 miliar \\
\hline
\end{tabular}

Sumber : UU No. 20 tahun 2008

Dengan adanya kriteria tentang UMKM di Indonesia seperti dalam dijelaskan di Tabel 1, menurut Jacky Mussry, Executive Vice President International Council for Small Business (ICSB) Indonesia, UMKM harus profesional, produktif, kreatif, dan be entrepreneurial. Keempatnya harus saling terkait. Para pelaku UMKM akan lebih diarahkan pada digital, tidak lagi bermain pada tataran konservatif tetapi harus dapat melihat peluang digital sehingga dapat menyasar pasar yang lebih luas.

Dalam situasi pandemi Covid-19 yang mengakibatkan dampak ekonomi yang besar, dibutuhkan langkah yang mantap dan antisipasi yang cepat untuk menghadapinya. Kebijakan stimulus harus diberikan untuk mengurangi dampak ekonomi khususnya pada kelompok rentan dan dunia usaha agar tidak sampai pada kebangkrutan. Teknologi digital diprediksi akan berdampak pada produktivitas. Mengoptimalkan penggunaan teknologi digital sebagai bagian dari adaptasi terhadap dampak Covid-19 juga dapat menjadi salah satu cara untuk mengatasi masalah kemiskinan. UMKM merupakan salah satu perekonomian bangsa yang selamat dari pandemi ini dan diharapkan dapat menghidupkan kembali perekonomian dunia. UMKM dapat menggunakan perdagangan online untuk mempromosikan produknya di mana saja. Pemerintah juga dituntut secara cepat untuk membuat terobosan-terobosan yang berkenaan dengan kebijakan yang akan diambil terkait pengembangan UMKM, seperti yang dikemukakan begawan hukum Indonesia 
Satjipto Rahardjo bahwa hukum progresif adalah "mengubah secara cepat, melakukan pembalikan yang mendasar dalam teori dan praksis hukum, serta melakukan berbagai terobosan. Hal ini didasarkan pada prinsip bahwa hukum adalah untuk manusia dan bukan sebaliknya dan hukum itu tidak ada untuk dirinya sendiri, melainkan untuk sesuatu yang lebih luas yaitu untuk harga diri manusia, kebahagiaan, kesejahteraan, dan kemuliaan manusia (Safaruddin Harahap, 2016). Oleh karena itu, sebagai wujud dukungan pemerintah kepada UMKM dalam masa pandemi, pemerintah juga harus membantu regulasi logistik agar biaya pengiriman tidak mahal. Perlu segera dibuatkan payung hukum dalam bentuk Peraturan Presiden maupun regulasi di tingkat daerah yaitu peraturan daerah seperti kewenangan yang ada dalam UUD NRI Tahun 1945 Pasal 18 Ayat (6) Pemerintah daerah berhak menetapkan peraturan daerah dan peraturan-peraturan lain untuk melaksanakan otonomi dan tugas pembantuan. Kurangnya dukungan kebijakan, membuat sektor usaha kecil kurang mapan sehingga dapat berdampak buruk pada hilangnya mata pencaharian penduduk karena kalah bersaing dengan pelaku usaha besar. Penyelenggaraan pemerintah daerah sebagai subsistem negara dimaksudkan untuk meningkatkan daya guna dan hasil guna dalam penyelenggaraan pemerintah daerah dan pelayanan masyarakat. Pemberdayaan Pelaku usaha kecil (UMKM) di daerah seperti NTT diharapkan akan mampu memberikan rasa keadilan, karena sejatinya keadilan adalah merupakan ruh dari isi hukum dalam setiap kehidupan. Pemberdayaan daerah merupakan wujud pembangunan daerah sebagai bagian integral dari pembangunan nasional yang dilaksanakan berdasarkan prinsip otonomi daerah. Hal ini ditujukan untuk memberi kesempatan bagi peningkatan kinerja daerah dalam rangka meningkatkan kesejahteraan masyarakat. Selanjutnya Jhon Rawls dalam bukunya A Theory of Justice berpendapat bahwa keadilan adalah kebijakan utama dalam institusi sosial, sebagaimana kebenaran dalam sistem pemikiran. Sebagai kebajikan utama umat manusia, kebenaran dan keadilan tidak bisa diganggu gugat. Lebih lanjut, Rawls mengatakan bahwa perlu adanya keseimbangan, kesebandingan, dan keselarasan (harmoni) antara kepentingan pribadi dengan kepentingan masyarakat, termasuk didalamnya negara. Menyoal tentang keadilan tidak lepas dari sistem hukum itu sendiri yang dimaknai sebagai kombinasi dari aturan primer dan aturan sekunder. Aturan Primer (primary rules) mengatur perilaku manusia untuk berbuat atau tidak berbuat, sedangkan aturan sekunder (secoundary rules) merupakan aturan yang ditujukan kepada pejabat dan yang ditetapkan untuk mengatur tentang bagaimana tata cara atau prosedur melaksanakan aturan primer (Liu \& Sukmariningsih, 2021). Sehingga dalam konteks ini diharapkan Pemerintah segera memberikan payung hukum sebagai norma primer yaitu platform digital sebagai manifestasi untuk mempertemukan UMKM dengan pembeli dan pemasok mereka selama pandemi dan Indonesia termasuk negara terdampak, karena dalam analisis penelitian ini terdapat ketimpangan terkait akses platform digital, terutama antara wilayah barat dan timur. 
Sedangkan norma sekundernya adalah perlu dibentuk peraturan daerah yang sasarannya adalah UMKM. Keterbatasan ruang gerak menjadi sumber utama permasalahan khususnya UMKM yang memiliki karakteristik sebagai berikut: 1. Produk berupa barang / jasa yang dikonsumsi langsung oleh masyarakat (consumer goods /jasa) 2. Kegiatan utama bersifat harian (daily basis). 3. Transaksi masih konvensional (tatap muka) dan menggunakan tunai (cash basis) 4. Pengelolaan keuangan masih sederhana. 5. Pola pikir pemiliknya tradisional dan tingkat pendidikannya rendah. 6. Status usaha informal (tidak terdaftar, berlisensi, dan terstandar produknya) Jenis UMKM yang berbeda memerlukan kebijakan yang berbeda pula. Masih terdapat ketimpangan pembangunan di Indonesia, terutama antara wilayah barat dan timur. Di kawasan timur, go digital menjadi isu penting. Dari wawancara yang dilakukan dengan UMKM di NTT ditemukan bahwa selama pandemi penjualan mereka mengalami penurunan hingga mencapai 75 persen. Sebagian besar masalah yang dialami oleh UMKM adalah tidak memahami cara penggunaan teknologi, sulitnya menjual produk dan kekurangan modal. Para pelaku UMKM berharap mendapatkan pendampingan dalam promosi penjualan, modal usaha dan permodalan untuk bahan mentah serta monitoring. Saat ini interaksi antar manusia telah melalui teknologi, secara tidak langsung semua proses yang dulunya dilakukan secara konvensional sekarang mulai beralih ke digital. Hal ini merupakan salah satu efek dari adanya revolusi industry 4.0. "Dampak era revolusi industry 4.0 adalah teknologi digital yang digunakan memungkinkan terjadinya intekoneksi antara mesin fisik dengan system produksi.teknologi menjadi unsur utama tehadap pengembangan industri konvensional menuju industri digital sehingga mampu mentransfer data tanpa bantuan manusia serta dengan adanya big data agar mampu membantu dalam menentukan arah dalam bisnis.

Untuk mendorong literasi digital, pemerintah dan pihak-pihak yang berkepentingan perlu memberikan pelatihan digital kepada UMKM yang komprehensif terkait pengembangan bisnis digital dan keahlian digital, kehadiran merek secara digital, kiat sukses berjualan di e-commerce, pemasaran dan pengoperasian digital. Peran pemerintah yang teramat vital dalam upaya UMKM Go digital adalah mempercepat penyediaan jaringan dan infrastruktur, terutama di wilayah yang belum terjangkau teknologi 4G. Pemerintah juga perlu membantu dengan regulasi dalam logistik agar biaya pengiriman tidak mahal. Sebagai konsumen, perlu mendukung upaya penguatan UMKM yang sudah pasti akan memperlancar perputaran roda ekonomi bangsa dengan membeli produk mereka. Pemasok pun juga harus melakukan revolusi dengan manajemen berbasis teknologi informasi agar usaha yang di lakukan lebih efektif dan efisien. Pihak swasta terutama yang berkaitan dengan perbankan dan lembaga keuangan lainnya perlu berkolaborasi dengan UMKM dengan menyediakan aplikasi pembayaran secara digital untuk memudahkan proses transaksi. Media juga berperan penting dalam memberikan informasi yang edukatif kepada UMKM dan 
merupakan salah satu sarana yang efektif dalam mempromosikan UMKM.

\section{Kebijakan Pemerntah Dalam Rangka Memfasilitasi UMKM Untuk Meningkatkan Pertumbuhan Ekonomi Dimasa Pandemi}

Saat ini krisis ekonomi yang masih sedang melanda dunia termasuk di dalamnya Indonesia, banyak pelaku usaha khususnya pelaku yang terkena dampak adanya krisis ekonomi yang disebabkan oleh pandemi Covid-19. Perlu adanya inovasi dan kreatifitas dari pelaku UMKM agar usahanya dapat terus bertahan dan berkembang dalam situasi saat ini (Chaerani et al., 2020).

Pandemi Covid-19 telah mengakibatkan situasi VUCA (Volatility, Uncertainty, Complexity dan Ambiguity). Volatility adalah dinamika perubahan yang sangat cepat dalam berbagai hal seperti sosial, ekonomi, dan politik. Uncertainty karena sulitnya memprediksi isu dan peristiwa yang saat ini sedang terjadi. Complexity merupakan keadaan yang sangat kompleks karena banyaknya hal yang sangat sulit diselesaikan. Sedangkan ambiguity yakni keadaan yang terasa mengambang dan kejelasannya masih dipertanyakan.

Pada saat seperti ini, kebijakan yang disarankan untuk mendukung penurunan biaya produksi atau biaya operasional antara lain dengan (Liu \& Sukmariningsih, 2021):

a. Pemberian keringanan (subsidi) bunga kredit. Misalnya dengan memperluas cakupan KUR dengan mempertimbangkan existing loans; menurunkan premi resiko UMKM pada situasi tertentu;

b. Pemberian keringanan (subsidi) pajak dan/atau tarif listrik;

c. Peningkatan frekuensi pelatihan untuk menjangkau lebih banyak UMKM;

d. Peningkatan peluang permintaan barang dan jasa bagi UMKM serta perluasan program kemitraan usaha besar dengan UMKM;

e. Pengembangan e-commerce sebagai platform bagi UMKM dalam berusaha/bertransaksi. Ecommerce menawarkan platform bertransaksi yang sangat efisien terutama dari sisi unit usaha; dan

f. Pemerintah membuat kebijakan dengan cara membuka lapangan bagi pelaku UMKM di sekitaran kota Medan.

Kebijakan pemerintah dalam membantu UMKM keluar dari dampak negarif Covid-19 dengan menyiapkan strategi jangka pendek yang meliputi penerapan protokol kesehatan, memberi peluang dan mendorong layanan digital sebagai pendukung UMKM, sosialisasi asosiasi pelaku usaha, penyederhanaan proses administrasi, serta upaya mendorong perubahan strategi bisnis. Sedangkan strategi jangka panjang meliputi penyiapan roadmap pengembangan UMKM, membangun teknologi digital sebagai platform dalam proses bisnis UMKM, pengembangan model bisnis UMKM yang modern, serta mendorong kolaborasi pemerintah dengan korporasi dalam 
memberdayakan UMKM (Sugiri, 2020). Pemerintah daerah melalui Dinas Koperasi dan UKM pun telah melakukan upaya untuk memfasilitasi UMKM agar dapat meningkatkan pertumbuhannya di masa pandemi ini, antara lain dengan: pendampingan dan pelatihan untuk meningkatkan SDM, memberikan bantuan peralatan dan bahan yang diperlukan UMKM untuk produksi, bantuan promosi penjualan melalui pameran online, offline dan sosial media.

Pemerintah Kota Medan, Sumatera Utara kembali membuka Kesawan City Walk (KCW) untuk mebangkitkan usaha mikro kecil dan menengah (UMKM) seiring membaiknya status level pemberlakuan pembatasan kegiatan masyarakat (PPKM) di daerah ini. Pembukaan KCW ditandai dengan kegiatan pekan kuliner kondang (PKK) UMKM yang digelar di seputaran Gedung Warenhuis kawasan Kota Lama Kesawan, Medan. Kegiatan pekan kuliner ini merupakan rangkaian pembukaan KCW, kegiatan ini dilakukan untuk membangkitkan UMKM daerah Kota Medan. Sebanyak 71 Usaha Mikro Kecil Menengah (UMKM) akan mengisi pembukaan kembali Kesawan City Walk, wali Kota Medan menyebut bahwa seluruh pengunjung di area KCW hanya bisa masuk jika memiliki aplikasi PeduliLindung. Pengecekan suhu tubuh juga dilakukan di setiap pintu masuk guna memastikan pelaksanaan prokes berjalan dengan baik, satuan tugas penanganan COVID-19 secara rutin akan berkeliling untuk menghimbau pengunjung dan pelaku UMKM. Spot kuliner bernama Kesawan City Walk yang resmi dibuka pada 28 April 2021. Spot kuliner ini mengusung tema The Kitchen of Asia, yakni perpaduan antara beragam kuliner menggugah selera dan budaya Asia. Kesawan City Walk sendiri merupakan destinasi wisata kota tua yang menghadirkan deretan bangunan tua berestetika dan sarat akan sejarah dan budaya Asia.

Untuk semakin menarik minat para pengunjung, Boby Nasution selalu Walikota Medan pun berinisiatif untuk menyulap kawasan tersebut menjadi sentra kuliner yang berpadu budaya Asia, dengan tema The Kitchen of Asia bagi para pecandu kuliner, berkunjung kesini bukan hanya bisa melihat dan mencicipi beragam kuliner yang tersaji, tapi juga bisa melihat bagaimana proses memasaknya karena dapur dibuat terbuka.

\section{SIMPULAN}

Berdasarkan UU Nomor 20 Tahun 2008 Tentang UMKM, usaha mikro adalah usaha produktif milik orang perorangan atau badan usaha perorangan yang memenuhi kriteria usaha mikro sebagaimana diatur dalam UU tersebut diantaranya; Usaha kecil adalah usaha ekonomi produktif yang berdiri sendiri, yang dilakukan oleh orang perorangan atau badan usaha yang bukan merupakan anak perusahaan atau bukan cabang perusahaan yang dimiliki, dikuasai, atau menjadi bagian baik langsung maupun tidak langsung dari usaha menengah atau usaha besar yang memenuhi kriteria usaha kecil sebagaimana dimaksud dalam UU tersebut yaitu; Usaha menengah adalah usaha ekonomi produktif yang berdiri sendiri, yang dilakukan oleh orang perorangan atau badan usaha yang bukan yang bukan merupakan anak perusahaan atau cabang perusahaan yang dimiliki, dikuasai, atau menjadi bagian baik langsung maupun tidak langsung dengan usaha kecil atau usaha besar dengan jumlah kekayaan bersih atau hasil penjualan tahunan sebagaimana diatur dalam UU tersebut.

Dalam situasi pandemi Covid-19 yang mengakibatkan dampak ekonomi yang besar, dibutuhkan langkah yang mantap dan antisipasi yang cepat untuk menghadapinya. Setelah adanya penemuan komputer dan laptop pantas jika dikatakan bahwa komputer adalah penemuan yang paling mutakhir dan yang paling berpengaruh pada kehidupan manusia karena hampis semua pekerjaan manusia dapat dipermudah sehingga dunia usaha juga sudah sangat terikat dengan 
komputer atau laptop. Ditambah lagi dengan adanya pandemi Covid-19 di masa sekarang ini banyak membawa dampak buruk bagi pelaku UMKM tetapi di sisi lain hal ini menjadi peluang besar bagi para pelaku UMKM yang memiliki inovasi lebih dalam memanfaatkan teknologi digital sehingga mereka dapat meningkatkan omzet penjualan serta dapat membuat inovasi baru terhadap produk usaha mereka. Di Indonesia, sudah tampak banyak UMKM yang mempersiapkan usaha mereka dalam menggunakan teknologi digital dimulai dengan adanya pelaku usaha yang berjualan di media sosial. Namun masih ada juga beberapa pelaku usaha yang belum bersentuhan dengan teknologi digital diakibatkan oleh satu dan lain hal.

Di masa seperti ini krisis ekonomi menyerang ke hampir seluruh negara termasuk salah satunya Indonesia, banyak pelaku usaha terkena dampak krisis ekonomi yang disebabkan oleh pandemi Covid-19. Ada beberapa kebijakan pemerintah yang dilakukan untuk membantu para pelaku UMKM keluar dari dampak Covid-19. Pemerintah juga dituntut untuk melakukan terobosan-terobosan baru untuk mengembangkan UMKM. Salah satu hal yang dilakukan oleh Pemerintah Kota Medan adalah dengan kembali membuka Kesawan City Walk (KCW) untuk membangkitkan UMKM seiring dengan membaiknya status level PPKM di daerah tersebut. Hal tersebut dilakukan dengan tujuan untuk membangkitkan UMKM di daerah Kota Medan. Sebanyak 71 pelaku UMKM akan mengisi kembali lapak-lapak di Kesawan City Walk (KCW). Pengunjung hanya bisa masuk dengan syarat sudah mendapatkan vaksinasi minimal dosis 1 , mengecek suhu tubuh, dan tetap memberlakukan protokol kesehatan.

\section{BIBLIOGRAFI}

Aminah, S. (2020). Membangkitkan UMKM di Masa Pandemi dengan Inovasi dan Teknologi. LIPI.Go.Id, http://lipi.go.id/siaranpress/membangkitkan-umkm-d. http://lipi.go.id/siaranpress/membangkitkan-umkm-di-masa-pandemi-dengan-inovasi-danteknologi/22212

Amri, A. (2020). Pengaruh Periklanan Melalui Media Sosial Terhadap UMKM di Indonesia di Masa PAndemi. Jurnal Brand, 2(1), 123-130. https://www.academia.edu/42672824/Dampak_Covid-19_Terhadap_UMKM_di_Indonesia

Chaerani, D., Talytha, M. N., Perdana, T., Rusyaman, E., \& Gusriani, N. (2020). Pemetaan Usaha Mikro Kecil Menengah (Umkm) Pada Masa Pandemi Covid-19 Menggunakan Analisis Media Sosial Dalam Upaya Peningkatan Pendapatan. Dharmakarya, 9(4), 275. https://doi.org/10.24198/dharmakarya.v9i4.30941

Helmi, S. (2021). Analisis data (Issue July).

Kartono, K. (1976). Pengantar metodologi research sosial. Alumni. http://digilib.fisipol.ugm.ac.id/handle/15717717/11060

Lili Marlinah. (2020). Peluang dan Tantangan UMKM Dalam Upaya Memperkuat Perekonomian Nasional Tahun 2020 Ditengah Pandemi Covid 19. Jurnal Ekonomi, 22(2), 118-124.

Liu, E., \& Sukmariningsih, R. M. (2021). Membangun Model Basis Penggunaan Teknologi Digital Bagi Umkm Dalam Masa Pandemi Covid-19. Jurnal Ius Constituendum, 6(1), 213. https://doi.org/10.26623/jic.v6i1.3191

Muttaqin, Z., \& Murtadho, M. A. (2011). Perancangan Pusat Komunikasi Bisnis UMKM Berbasis Sistem Terintegrasi. Seminar Nasional Competitive Advantage, 1. 
Rianti, W. (2016). Jurnal paud tambusai. Jurnal PAUD Tambusai, 2(2), 36-42.

Safaruddin Harahap, I. (2016). Perlindungan Hukum Terhadap Anak Korban Kejahatan Seksual dalam Perspektif Hukum Progresif. Jurnal Media Hukum, 23(1), 37-47. https://doi.org/10.18196/jmh.2015.0066.37-47

Sugiri, D. (2020). Menyelamatkan Usaha Mikro, Kecil dan Menengah dari Dampak Pandemi Covid-19. Fokus Bisnis : Media Pengkajian Manajemen Dan Akuntansi, 19(1), 76-86. https://doi.org/10.32639/fokusbisnis.v19i1.575

Sumarni, Y. (2020). Pandemi Covid 19: Tantangan Ekonomi dan Bisnis. Al-Intaj Jurnal Ekonomi Dan Perbankan Syariah, 2(1), 46-58. 